THE KURUME MEDICAL JOURNAL Vol. 1, No. 2, 1954

\title{
ON THE GROUP-SPECIFIC SUBSTANCE OF
} ASCARIS LUMBRICOIDES.

\author{
SHINICHIRO OTA and HIROSHI TADOKORO \\ Department of Legal-medicine, Kurume University School \\ of Medicine, Kurume-shi, Japan.
}

Oliver-González et al (1), (2), (3), (4) reported the presence of A and B group substances as well as Forssman's antigen in each of Ascaris lumbricoides, Ascaris suum, Trichnella spiralis, Necator americanus, Schistosoma mansoni, Cysticercus cellulosae and Taenia solium.

Yamaguchi (5) found the existence of A partial antigen of A group substance and Forssman's antigen in the larva of gnathostoma spinigerum. In 1952 Ota (6) confirmed that $\mathrm{A}_{\mathrm{IV}}$ partial antigen of $\mathrm{A}$ group substance, $\mathrm{C}$ group substance and Forssman's antigen were contained in Ascaris Lumbricoides and that both of $A n$ cylostoma duodenale and that both of Ancylostoma duodenale and Taeniarhynchus saginatus had at least $A_{1 V}$ partial antigen of $A$ group substance.

\section{MATERIALS AND METHODS}

Ascaris lumbricoides was washed with water and crashed. Ten volumes of physiological saline were added to the crashed materials and shaken sufficiently. The supernatant fluids were used for the following tests.

Absorption test. The absorbent material was added to the antisera and allowed to stand at $37 \mathrm{C}$ for 2 hours, then $2 \mathrm{C}$ over night beeing shaken. When the absorption was considered to be insufficient, the absorption procedure was repeated.

Immunization. Blood cells of human $\mathrm{B}$ and $\mathrm{O}$ group, rabbit, white rat and guinea-pig were washed sufficietly with physiological saline and diluted to ten per cent. These blood cell suspensions were injected 7 times intravenously at 2 to 3 days intervals to healthy mature domestic fowls previously proved free of normal precipitins.

Precipitin reaction. The usual ring method was used at the room temperature, 


\section{EXPERIMENTAL}

Preparation of anti $B$, anti $B_{\mathrm{I}}$, anti $B_{\mathrm{II}}$ and anti $B_{\mathrm{III}}$ precipitin. After absorption of anti human $B$ group blood cells domestic fowl sera with human A group blood cells, anti B precipitin sera presented positive precipitin reaction with only human BS and ABS type saliva. When anti-B precipitin sera were absorbed sufficiently with rabbit blood cells, anti $B_{1}$ precipitin sera were confirmed to show positive precipitin reaction only with human BS and ABS type saliva. Anti $B_{I I}$ precipitin sera were prepared by means of absorption of anti rabbit blood cells domestic fowl sera with human A Group blood cells or guinea-pig blood cells. These anti $B_{I I}$ precipitin sera were found to react with only human BS and ABS type saliva.

Anti $B_{\text {III }}$ precipitin sera obtained by absorption of anti guinea-pig blood cells domestic fowl sera with human A group blood cells were determined to present positive precipitin reaction with human BS and ABS type saliva.

Preparation of anti $O_{\mathrm{I}}$, anti $O_{\mathrm{II}}$ and anti $O_{\mathrm{III}}$ precipitin. When anti human $O$ group blood cells domestic fowl sera were absorbed with human AB group blood cells or further with rat blood cells, those absorbed sera reacted with only human OS type saliva, thus anti $\mathrm{O}_{\mathrm{I}}$ precipitin were obtained.

Similary, anti $\mathrm{O}_{\mathrm{II}}$ and anti $\mathrm{O}_{\mathrm{III}}$ precipitin sera were prepared respectively by means of absorption of anti rat blood cells domestic fowl sera with human $A B$ group blood cells or further with rabbit blood cells, and by means of absorption of anti rabbit blood cells donnestic fowl sera with human $\mathrm{AB}$ group blood cells.

Precipitin reaction between the extract of Ascaris lumbricoides and anti $B$ precipitin sera was positive in dilution up to $1: 16$. When anti $B$ precipitin sera containing anti $\mathrm{B}_{\mathrm{I}}$, anti $\mathrm{B}_{\mathrm{II}}$ and anti $\mathrm{B}_{\mathrm{III}}$ precipitin were absorbed with guinea-pig cells, anti $B_{\text {III }}$ precipitin was absorbed and, therefore, both of anti $B_{I}$ and anti $B_{I I}$ precipitin were remained. The extract of Ascaris lumbricoides presented negative reaction with anti $B_{I}$ or anti $B_{I I}$ precipitin sera.

Precipitin reaction between the extract of Ascaris lumbricoides and anti $B_{\text {III }}$ precipitin sera was positive in dilution up to $1: 8$. Though these antisera showed also positive precipitin reaction with human BS type saliva in dilution up to $1: 128$, the reaction became negative by absorption of the antisera with the extract of Ascaris lumbricoides.

Precipitin reaction between the extract of Ascaris lumbricoides and anti $B_{\mathrm{I}}$ or anti $B_{\mathrm{II}}$ precipitin sera was proved negative. Anti $\mathrm{B}_{\mathrm{I}}$ precipitin sera showed positive reaction with human BS type saliva in dilution up to $1: 128$. But when 
anti $\mathrm{B}_{\mathrm{I}}$ precipitin sera were absorbed with the extract of Ascaris lumbricoides, the precipitin titer did not become low. Anti $B_{\text {II }}$ precipitin sera presented positive reaction with human $B S$ type saliva in dilution up to $1: 256$, and there were no remarkable changes of reactions after the absorption of the sera with the extract of Ascaris lumbricoides.

Precipitin reaction between the extract of Ascaris lumbricoides and anti $O_{11 I}$ precipitin sera was positive in dilution up to $1: 32$. These anti sera aiso showed positive reaction with human OS type saliva in dilution up to $1: 128$. But when the sera were absorbed with the extract of Ascaris lumbricoides, they showed negative precipitin reactions.

Precipitin reaction between the extract of Ascaris lumbricoides and anti $O_{\mathrm{I}}$ precipitin sera was found negative. Anti $\mathrm{O}_{\mathrm{II}}$ precipitin sera showed positive reaction with human OS type saliva in dilution up to $1: 128$, and anti $\mathrm{O}_{\mathrm{I}}$ precipitin sera showed also positive reaction with human OS type saliva in dilution up to $1: 128$. Both of anti $\mathrm{O}_{\mathrm{I}}$ and anti $\mathrm{O}_{\mathrm{II}}$ precipitin sera presented very little decrease of precipitin titers, when they were absorbed with the extract of Ascaris lumbricoides.

\section{DISCUSSION}

From the fact that anti $\mathrm{B}_{\mathrm{III}}$ and anti $\mathrm{O}_{\mathrm{III}}$ precipitin sera presented positive precipitin reactions with the extract of Ascaris lumbricoides and these precipitins could be absorbed completely by the extract of $A$. lumbricoides, we confirmed that $A$. lumbricoides contained $\mathrm{B}_{\mathrm{III}}$ partial antigen of $\mathrm{B}$ group substance as well as $\mathrm{O}_{\mathrm{III}}$ partial antigen of $\mathrm{O}$ group substance. On the other hand, the fact that the extract of $A$. lumbricoides did not react with anti $\mathrm{B}_{\mathrm{II}}$, anti $\mathrm{B}_{\mathrm{I}}$, anti $\mathrm{O}_{\mathrm{II}}$ and anti $\mathrm{O}_{\mathrm{I}}$ precipitin sera and these precipitins could not be absorbed by the absorption test demonstrated that $A$. lumbricoides contained none of $\mathrm{B}_{\mathrm{II}}$ and $\mathrm{B}_{\mathrm{I}}$ partial antigens of $\mathrm{B}$ group substance, $\mathrm{O}_{\mathrm{II}}$ and $\mathrm{O}_{\mathrm{I}}$ partial antigens of $\mathrm{O}$ group substance. In the previous paper Ota, one of the authors, had already reported the presence of $A_{\text {IV }}$ partial antigen of A group substance, C type substance and Forssman's antigen in Ascaris lumbricoides. From the results of the previous and the present experiments, it must be concluded that there are $A_{I V}, B_{I I I}$ and $O_{I I I}$ partial antigens, $\mathrm{C}$ group substance and Forssman's antigen in Ascaris lumbricoides.

On the fundamental of the experimental results obtained by Oliver-González et $a l$ in which the presence of $\mathrm{A}$ and $\mathrm{B}$ substances in Ascaris lumbricoides were confirmed, we further analyzed the partial antigens contained in A. lumbricoides in detail. The fact that we could determine the existence of group specific 
substances in $A$. lumbricoides by means of analysing partial antigens would be considered to be a new finding.

\section{SUMMARY}

We prepared anti $B$, anti $B_{I}$, anti $B_{I I}$, anti $B_{I I I}$, anti $\mathrm{O}_{I}$, anti $\mathrm{O}_{I I}$ and anti $\mathrm{O}_{I I I}$ precipitin sera in order to try precipitin tests and absorption tests with the extract of Ascaris lumbricoides. In these studies, the presence of $\mathrm{B}_{\mathrm{III}}$ partial antigen of $\mathrm{B}$ group substance and $\mathrm{O}_{\text {III }}$ partial antigen of $\mathrm{O}$ group substance were confirmed in Ascaris lumbricoides.

\section{REFERRENCES}

(1) Oliper-González, J. and Torregrosa, M. V. : A substance in animal parasites related to the human isoagglutinogen. J. Inf. Dis., Vol. 74, 1944.

(2) Oliver-González, J.: The inhibition of human isoagglutinins by a polysaccharide from Ascaris suum. J. Inf. Dis., Vol 75, 1944.

(3) Otiver-González, J.: Immunological relationship among polysaccharide from various infections organs. J. Inf. Dis., Vol. 79, 1946.

(4) Oliver-González, J. and González, L. M.: Release of the $\mathbf{A}_{2}$ isoagglutinogenlike substance of infections organisms into human blood serum. J. Inf. Dis., Vol. 85, 1949.

(5) Yamaguchi, T.: Immunological studies on human Gnathostomiasis. (IV. On the antigenicity). J. KUR. M. A., Vol. 15, No. 3, 4. 1952.

(6) Ота, S.: Serological studies of the Ascaris lumbricoides, Acta medica., Vol. 23, No. 6. 1953. (in Japanese). 